\title{
Characteristic of synthesis and transformations of hardystonite in willemite glass-crystalline glaze based on thermal analysis
}

\author{
Katarzyna Gasek $^{1} \cdot$ Janusz Partyka $^{1} \cdot$ Marcin Gajek $^{1} \cdot$ Wojciech Panna $^{1}$
}

Received: 14 October 2015/Accepted: 28 March 2016/Published online: 12 April 2016

(c) The Author(s) 2016. This article is published with open access at Springerlink.com

\begin{abstract}
A new crystalline phase hardystonite $\left(\mathrm{Ca}_{2}\right.$ $\mathrm{ZnSi}_{2} \mathrm{O}_{7}$ ) has been obtained in willemite glass-ceramic glaze containing more than $20 \%$ by mass $\mathrm{ZnO}$. To our knowledge, there was no report about the presence of this calcium zinc silicate in glazes. The aim of this study was to investigate the synthesis and thermal behavior of $\mathrm{Ca}_{2}$ $\mathrm{ZnSi}_{2} \mathrm{O}_{7}$ in ceramic glaze. A hardystonite formed in glaze at $750{ }^{\circ} \mathrm{C}$ and exist to $850{ }^{\circ} \mathrm{C}$, as confirmed by $\mathrm{X}$-ray phase powder diffraction findings and scanning electron microscope image (SEM) with chemical elemental analysis. The second formed of zinc calcium silicate is corresponding with liquid phase presence in glaze observed at $1150{ }^{\circ} \mathrm{C}$ and also decompose below $1200{ }^{\circ} \mathrm{C}$. Because glaze is complicated multi-component system with different crystalline phases, it is developed for research transformations in stoichiometric hardystonite. On this basis, an oxide system was prepared from $\mathrm{SiO} 2, \mathrm{ZnO}$ and $\mathrm{CaCO}_{3}$ to designated precise chemical synthesis temperature of pure hardystonite powders. Thermal analysis method such as differential scanning calorimetry has confirmed that in $1175^{\circ} \mathrm{C}$ formed hardystonite according to $\mathrm{X}$-ray phase powder diffraction of a reaction mixture. Hot-stage microscope is useful to detailed description of the processes and transformations which occur when mixture and glaze were heated. SEMs of the new phase in mixture and in glaze are presented. Phenomena related with the influence of heating cycle and liquid phase on the
\end{abstract}

Katarzyna Gasek

gasek@agh.edu.pl

1 Department of Ceramic and Refractory Materials, Faculty of Material Science and Ceramic, AGH University of Science and Technology, al. Mickiewicza 30, 30-059 Kraków, Poland transformation of hardystonite are examined and analytically discussed.

Keywords Hardystonite $\cdot$ Willemite $\cdot$ Glaze $\cdot$ Sinteringcrystallization $\cdot$ Hot-stage microscopy (HSM) $\cdot$ DSC

\section{Introduction}

Glass-ceramic science opens a wide range of possibilities for designing new materials. The properties of glass-ceramics are mainly determined by their constituent phases and microstructures, which depend on the composition and thermal treatment of used raw materials [1]. Willemite glass-crystalline glazes characterized by a glassy matrix containing the spherulites of willemite clearly visible to the naked eye that can be $10 \mathrm{~cm}$ or more in radius [1-3]. These glazes belong to special kind of decorative ceramic glazes, due to possibility achievement a wide range of colors these crystals [4]. The crystals collect a pigment or coloring ions in the glaze. Some common oxides are chromium, cobalt, copper, iron, manganese, nickel, rutile (titanium) and other oxides $[4,5]$. The amount of oxides in the glaze usually ranges between 0.5 and $5 \%$ [4]. Colorants can be combined to produce unique color and crystal combinations [2-5]. In these glazes, not only willemite crystals can be colored. The glassy matrix also can embed metal ions and give it different hue of color compared to color of the crystals [2,4]. Willemite is an orthosilicate containing zinc $\left(\mathrm{Zn}_{2} \mathrm{SiO}_{4}\right)$ and a main crystalline phase in decorative glassceramic glazes containing more than $20 \%$ by mass $\mathrm{ZnO}$ $[2,6,7]$. Willemite glass-crystalline glaze belongs to multicomponent oxides system consisting of $\mathrm{ZnO}-\mathrm{SiO}_{2}-\mathrm{CaO}-$ $\mathrm{K}_{2} \mathrm{O}-\mathrm{Na}_{2} \mathrm{O}-\mathrm{Al}_{2} \mathrm{O}_{3}$. It should be noted that the more complex the composition of the glaze is, the greater diversity of 
the expected crystalline phases will be. In view of decorative aspect of this kind of glazes, crystallization of other phases than willemite is not advisable [1, 8]. A new crystalline phase hardystonite $\left(\mathrm{Ca}_{2} \mathrm{ZnSi}_{2} \mathrm{O}_{7}\right)$ has been obtained in willemite glass-crystalline glaze [8]. Recently, hardystonite is a popular crystal phase in bioceramics due to improved bending strength and fracture toughness as compared to hydroxyapatite and may possess good biocompatibility [9]. Moreover, a great deal of interest has been focused on the studies of properties doped hardystonite as a luminescent material [10]. However, the literature review not reported any information about hardystonite in glazes. Jamaludin [11] studied influence of $\mathrm{CaCO}_{3}$ addition on the phase crystallization in willemite glass-crystalline glazes. Author focused on final crystalline phase composition of glaze, and probably, this was a reason of not registered a hardystonite in glaze. The only information about the formation of hardystonite derived from studies of glasses. Omar reported that hardystonite and willemite formed in calcium zinc aluminosilicate glass heat for $6 \mathrm{~h}$ at $750{ }^{\circ} \mathrm{C}$ [12].

This paper aims at studying the thermal behavior of hardystonite in willemite glass-ceramic glaze. Synthesis of hardystonite in solid phase and crystallization in melt silicate were investigated. The process of decompose and melted of this crystalline phase are also illustrated.

\section{Experimental}

\section{Glaze preparation}

The oxide composition of glass-crystalline glaze was based on multi-component system of $\mathrm{SiO}_{2}-\mathrm{ZnO}-\mathrm{CaO}-\mathrm{K}_{2} \mathrm{O}$ $\mathrm{Na}_{2} \mathrm{O}-\mathrm{Al}_{2} \mathrm{O}_{3}$. For the preparation of the experimental glaze, common raw materials were used: potassium feldspar (Norfloat K-600, Norway), zinc oxide (99.2 \% purity, Oława, Poland), quartz flour (Sobótka MK 40P, Poland) and calcium carbonate (K-45 Piotrowice, Poland). The raw materials and oxide composition of glaze in present study are shown in Table 1 . The proportioned mixture was ballmilled for $20 \mathrm{~min}$ in porcelain jars with a purified water medium to homogenize, and the resulting suspension was dried to form a powder. Dried powder was placed in bisque crucibles with a capacity of about $90 \mathrm{~g}$ and fired in an electric laboratory furnace with the temperature rate $5^{\circ} \mathrm{C} \mathrm{min}{ }^{-1}$. The heating temperature in the range $700-1240{ }^{\circ} \mathrm{C}$ with interval equal to $50{ }^{\circ} \mathrm{C}$ maintained for $1 \mathrm{~h}$ in maximum temperature, and then, samples were removed from the furnace due to the "freezing" processes taking place in them. The as-prepared samples were crushed into fine powders for determined crystalline phases composition by X-ray diffraction analysis (XRD) with an automatic PANalytical X'pert Pro system in range of $10^{\circ}$ $80^{\circ}$ with $\mathrm{CuK} \alpha$ radiation $(\lambda=1.5412 \AA)$. The quantitative determination of crystalline phases was performed from $\mathrm{X}$-ray diffraction patterns by using the Rietveld method [13]. The refinement was performed with program X'Pert HighScore. The thermal evolution and phase transformations in glaze were obtained by carrying out a differential scanning calorimetry (DSC) using Netzsch equipment (STA 449 F3 model) with a heating speed of $10{ }^{\circ} \mathrm{C} \mathrm{min}^{-1}$ in an air atmosphere. The temperature range studied varied from room temperature up to $1240{ }^{\circ} \mathrm{C}$. The sample mass was $40 \mathrm{mg}$. The sintering and melting behavior of the glaze was conducted using a hot-stage microscope (HSM) Misura Expert System Solutions coupled with software Misura $3.32 \mathrm{HSM}$. Sample was formed in $3 \mathrm{~mm}$ high and $2 \mathrm{~mm}$ diameter cylinder and measured with heating rate of $10{ }^{\circ} \mathrm{C} \mathrm{min}^{-1}$ up to until melting temperature. The evolution of the glaze microstructure was characterized at the micro-scale level performed by scanning electron microscope (JEOL scanning microscope JSM-5400) with energy dispersive $\mathrm{X}$-ray analysis (EDS).

\section{Reference hardystonite preparation}

Stoichiometric hardystonite was prepared by synthesis from raw materials: zinc oxide ( $99.2 \%$ purity), quartz flour (MK 40P) and calcium carbonate (K-45) as a reference material to compare with the same crystal phase obtained in the glaze. The composition of stoichiometric hardystonite is presented in Table 1. The mixture of raw materials prepared according to the glaze.

Table 1 The raw material composition (in mass\%) of willemite glass-crystalline glaze and mixture for the synthesis of stoichiometric hardystonite

\begin{tabular}{lllll}
\hline Sample & \multicolumn{2}{l}{ Raw material/mass\% } & & \\
\cline { 2 - 5 } & Calcium carbonate & Feldspar potassium & Quartz flour & Zinc oxide \\
\hline Glaze & 13.97 & 46.51 & 16.28 & 23.24 \\
Mixture for the synthesis of hardystonite & 49.83 & - & 29.91 & 20.26 \\
\hline
\end{tabular}




\section{Results}

\section{X-ray investigations of glaze samples}

The crystalline phase composition of the glaze after heating at temperatures between 700 and $1240{ }^{\circ} \mathrm{C}$ and holding for $1 \mathrm{~h}$ at the final temperature is displayed in Fig. 1. As it can be seen that the formation of hardystonite begins to be detectable by XRD after heating in the range between 750 and $850{ }^{\circ} \mathrm{C}$. Moreover, willemite coexists with hardystonite in the range between 750 and $800{ }^{\circ} \mathrm{C}$. The estimated amount of crystalline phases of glass-ceramic glaze specimens prepared after heating at range $700-1240{ }^{\circ} \mathrm{C}$ were determined by Rietveld refinement. The results of the refinements are displayed in Table 2. On the basis of experimental data contained in this table we can observe that the estimated content of hardystonite (21.3 mass\%) is higher than willemite (14.1 mass\%). The quantitative determination of the amount of hardystonite shows a tendency to decrease in the content of this crystalline phase between 750 and $850{ }^{\circ} \mathrm{C}$. The XRD pattern of glaze sample fired at $900{ }^{\circ} \mathrm{C}$ not indicates the presence of hardystonite crystalline phase in the system. With increasing of temperature up to $1150{ }^{\circ} \mathrm{C}$, willemite and hardystonite crystallized again. In this case, the determined by Rietveld method content of willemite phase (44.8 mass\%) was higher than hardystonite (29.3 mass\%). Hardystonite was not identified on the obtained X-ray diffraction patterns from samples fired at the maximum temperatures $1200{ }^{\circ} \mathrm{C}$ and $1240{ }^{\circ} \mathrm{C}$.

\section{Microstructures of glazes}

The microstructures of the glazes fired for $1 \mathrm{~h}$ at 750 and $1150{ }^{\circ} \mathrm{C}$ are depicted in Fig. 2. Observations revealed the presence of two kind of crystals having different colors. The white crystals belong to willemite. The oxide compositions of darker crystals marked points 1-4 (Fig. 2) are compatible with the stoichiometric crystal content of hardystonite (which are presented in Table 3) calculated based on the periodic table (for comparative purposes only). The crystals occurring in the glaze whose firing temperature increased seem to have lacked enough time to grow and the crystals of both crystalline phases are greater than in the glaze heated at $750{ }^{\circ} \mathrm{C}$. For glaze sample heated at $1150{ }^{\circ} \mathrm{C}$, the crystals of willemite and hardystonite characterized differential shapes. But the most of crystals are round-shaped. Furthermore, the size of the majority crystals of hardystonite is smaller in comparison to the size of the willemite crystals.

\section{Differential scanning calorimetry}

Figure 3 depicts the DSC and DDSC curves of willemite glass-crystalline glaze. Interpretation of the DSC curve is difficult due to the complex composition of the glaze. This allows to occurring large number of transformations and processes during firing. On DSC curve, the glaze is visible endothermic peak associated with reversible phase transition of $\alpha$-quartz to $\beta$-quartz [14] with minimum at $573{ }^{\circ} \mathrm{C}$. The second endothermic effect with the minimum at $739{ }^{\circ} \mathrm{C}$ is related with decomposition of calcium carbonate [15]. On DSC curve, it is not registered thermal effects associated with the formation of hardystonite. Therefore, it was necessary making a derivative DSC curve, which is present also on the Fig. 3. It is possible that after decomposition of calcium carbonate, the new phases (hardystonite and willemite) are created, which is observed as an exothermic effect at $750{ }^{\circ} \mathrm{C}$. This is confirmed by narrow, high exothermic peak right behind decomposition effect of calcium carbonate, what proof the high reactivity of calcium oxide. As then, next two endothermic peaks with minimum at temperature 902 and $927^{\circ} \mathrm{C}$ correspond to the decomposition of willemite and hardystonite in glaze. A sharp decline on the registered by DSC curve beginning above $1115^{\circ} \mathrm{C}$ indicated the onset of melting glaze. No thermal effects were recorded on the DSC and DDSC curves, which can be associated with crystallization of hardystonite. The last few exothermic effects on DDSC curve correspond with crystallization of willemite, and the only crystalline phase presents in glaze above $1200{ }^{\circ} \mathrm{C}$.

\section{Synthesized hardystonite}

A stoichiometric hardystonite has been prepared by synthesis process in order to compare the thermal behavior with such a crystalline phase obtained in the glaze. The hardystonite synthesis was realized on the basis of the results obtained after heating a stoichiometric mixture of $\mathrm{CaCO}_{3}, \mathrm{SiO}_{2}$ and $\mathrm{ZnO}$. Differential scanning calorimetry (DSC) was used with the same heating rate as glaze to observe the thermal behavior of this mixture. In the DSC curve as shown in Fig. 4, a transformation $\alpha \rightarrow \beta$-quartz point at $570{ }^{\circ} \mathrm{C}$ is observed [14]. An endothermic peak at $860{ }^{\circ} \mathrm{C}$ is attributable to the decomposition of calcium carbonate, and the largest mass loss band is found at this step [14]. In contrast, only one exothermic effect was registered on DSC curve with maximum at $1175{ }^{\circ} \mathrm{C}$, which may be ascribed to the synthesis of hardystonite. Figure 5 presents the XRD pattern after sintering at $1175^{\circ} \mathrm{C}$ for $1 \mathrm{~h}$ for mixture of $\mathrm{CaCO}_{3}, \mathrm{SiO}_{2}$ and $\mathrm{ZnO}$. The XRD result shows that the sintered material contains mainly hardystonite and only a small amount of willemite.

\section{Hot-stage microscopy}

The effect of the firing temperature on glaze and synthesized hardystonite was also studied from the sintering 


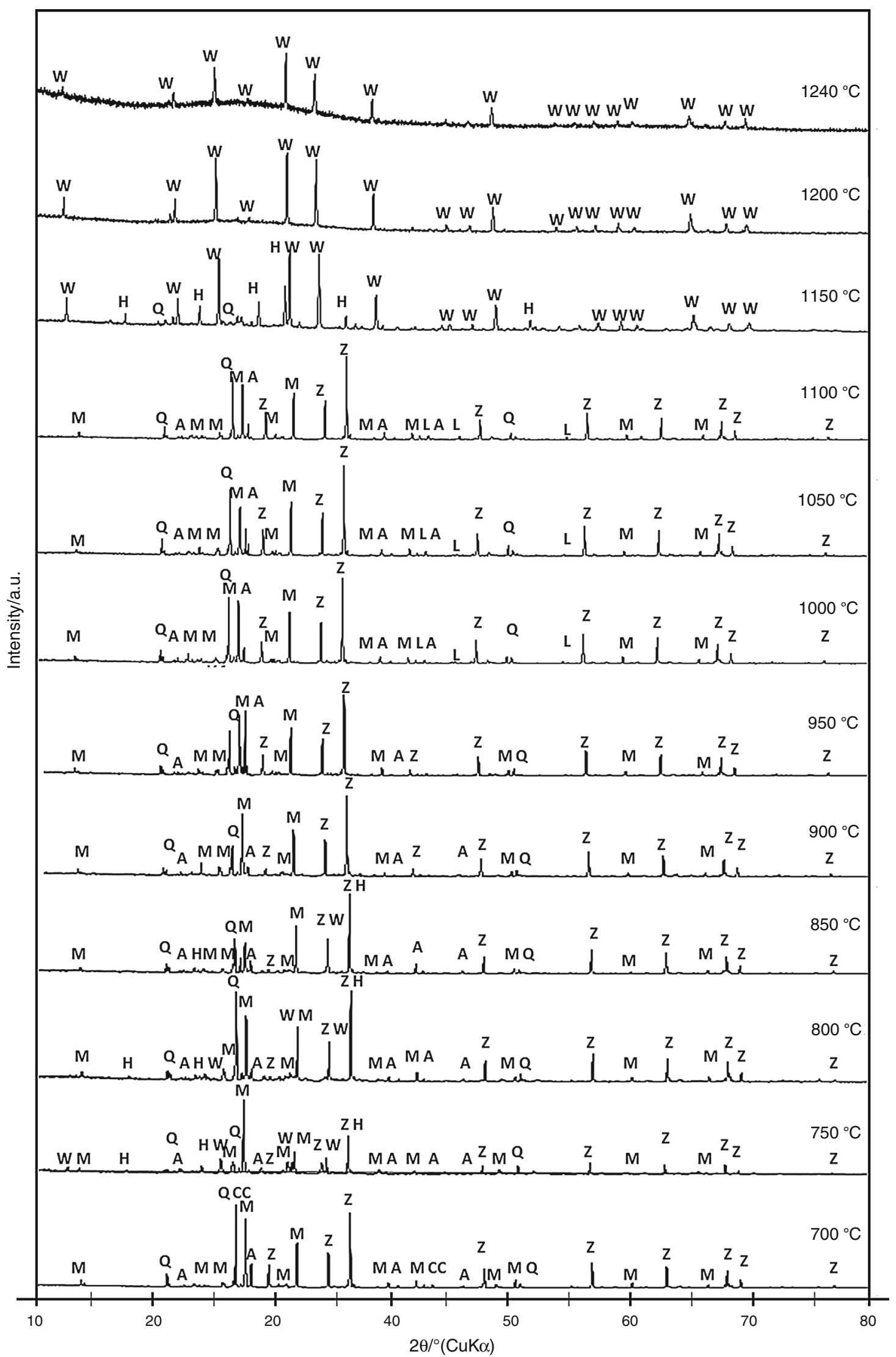


४Fig. 1 X-ray diffraction patterns for willemite glass-crystalline glaze heated for $1 \mathrm{~h}$ at different temperatures. Explanation of symbols: Aalbite, $\mathrm{CC}$-calcium carbonate, $\mathrm{H}$-hardystonite, L-leucite, $\mathrm{M}-$ microcline, Q-quartz, $\mathrm{W}$-willemite, $\mathrm{Z}$-zinc oxide curve obtained by HSM analysis. The detailed hot-stage microscope results of the willemite glass-ceramic glaze and reference hardystonite are given on Fig. 6. Three characteristic points in the sintering curve both materials

Table 2 Estimated phase composition of willemite glass-crystalline glaze determined by XRD-Rietveld (mass\%)

\begin{tabular}{|c|c|c|c|c|c|c|c|c|}
\hline \multirow[t]{2}{*}{$T /{ }^{\circ} \mathrm{C}$} & \multicolumn{8}{|c|}{ Content of crystal phases/mass $\%$} \\
\hline & $\begin{array}{l}\text { Albite } \\
\mathrm{NaAlSi}_{3} \mathrm{O}_{8}\end{array}$ & $\begin{array}{l}\text { Calcium carbonate } \\
\mathrm{CaCO}_{3}\end{array}$ & $\begin{array}{l}\text { Hardystonite } \\
\mathrm{Ca}_{2} \mathrm{ZnSi}_{2} \mathrm{O}_{7}\end{array}$ & $\begin{array}{l}\text { Leucite } \\
\mathrm{KAlSi}_{2} \mathrm{O}_{6}\end{array}$ & $\begin{array}{l}\text { Microcline } \\
\mathrm{KAlSi}_{3} \mathrm{O}_{8}\end{array}$ & $\begin{array}{l}\text { Quartz } \\
\mathrm{SiO}_{2}\end{array}$ & $\begin{array}{l}\text { Willemite } \\
\mathrm{Zn}_{2} \mathrm{SiO}_{4}\end{array}$ & $\begin{array}{l}\text { Zinc oxide } \\
\mathrm{ZnO}\end{array}$ \\
\hline 700 & 9.7 & 13.7 & - & - & 36.8 & 16.9 & - & 22.9 \\
\hline 750 & 9.6 & - & 21.3 & - & 36.1 & 7.1 & 14.1 & 11.8 \\
\hline 800 & 9.9 & - & 15.9 & - & 36.9 & 13.8 & 6.9 & 16.6 \\
\hline 850 & 10.1 & - & 12.1 & - & 32.7 & 16.4 & - & 18.7 \\
\hline 900 & 12.5 & - & - & - & 45.2 & 19.1 & - & 23.2 \\
\hline 950 & 11.4 & - & - & - & 44.5 & 21.3 & - & 22.8 \\
\hline 1000 & 11.6 & - & - & 12.9 & 32.9 & 20.9 & - & 21.7 \\
\hline 1050 & 9.6 & - & - & 8.4 & 38.8 & 19.7 & - & 23.5 \\
\hline 1100 & 1.1 & - & - & 5.2 & 92.0 & 0.8 & - & 0.9 \\
\hline 1150 & - & - & 29.3 & - & - & 29.3 & 44.8 & - \\
\hline 1200 & - & - & - & - & - & - & 100.0 & - \\
\hline 1240 & - & - & - & - & - & - & 100.0 & - \\
\hline
\end{tabular}

Fig. 2 SEM micrographs of powder willemite glasscrystalline glazes fired for $1 \mathrm{~h}$ at a $750{ }^{\circ} \mathrm{C}$, b $1150{ }^{\circ} \mathrm{C}$ (a)

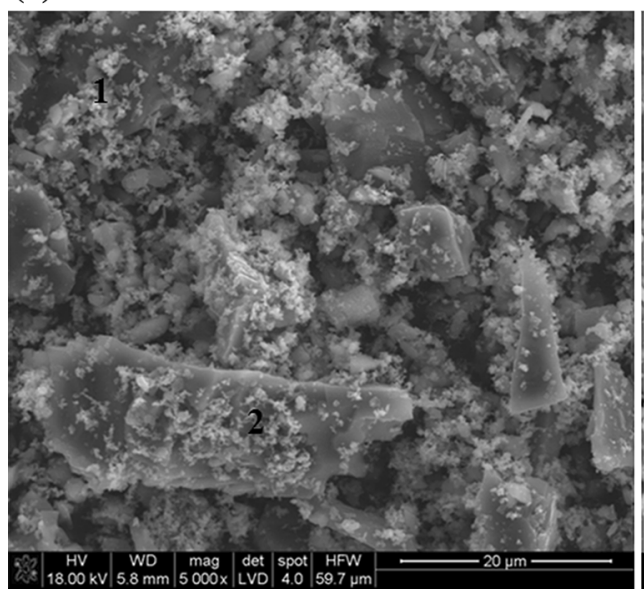

(b)

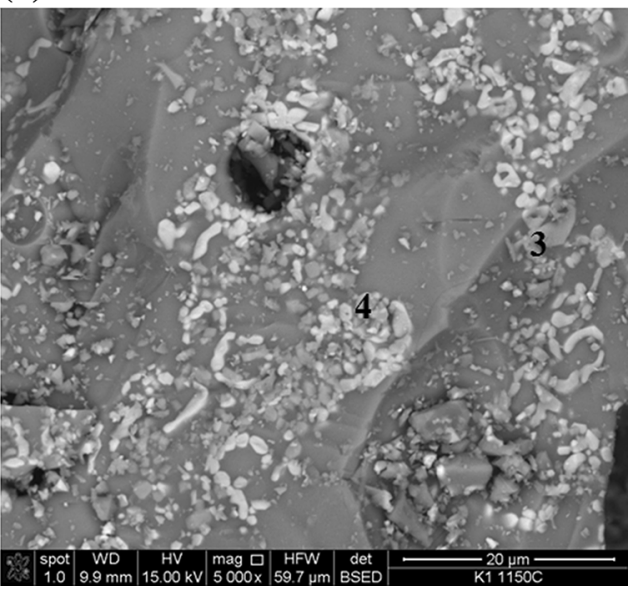

Table 3 Oxide composition of the stoichiometric crystal of hardystonite used only for comparison with the results of oxide composition of crystals in points $1-4$ (Fig. 3) obtained by EDS analysis

\begin{tabular}{llrrrr}
\hline $\begin{array}{l}\text { Oxide } \\
\text { composition/mass\% }\end{array}$ & Stoichiometric hardystonite $\mathrm{Ca}_{2} \mathrm{ZnSi}_{2} \mathrm{O}_{7}$ & Point 1 & Point 2 & Point 3 & Point 4 \\
\hline $\mathrm{SiO}_{2}$ & 38.30 & 35.46 & 36.17 & 37.56 \\
$\mathrm{ZnO}$ & 25.95 & 23.78 & 24.57 & 24.12 & 25.11 \\
$\mathrm{CaO}$ & 35.75 & 37.89 & 37.01 & 36.08 \\
$\mathrm{~K}_{2} \mathrm{O}$ & - & 1.32 & 1.06 & 0.95 \\
$\mathrm{Al}_{2} \mathrm{O}_{3}$ & - & 1.55 & 1.19 & 1.29 \\
\hline
\end{tabular}


Fig. 3 DSC and DDSC curves of powder willemite glasscrystalline glaze at heating rate of $10{ }^{\circ} \mathrm{C} \mathrm{min}{ }^{-1}$ up to $1240{ }^{\circ} \mathrm{C}$

Fig. 4 TG and DSC curves of stoichiometric mixtures $\mathrm{CaCO}_{3}$, $\mathrm{SiO}_{2}$ and $\mathrm{ZnO}$ at heating rate of $10{ }^{\circ} \mathrm{C} \mathrm{min}{ }^{-1}$ up to $1200{ }^{\circ} \mathrm{C}$
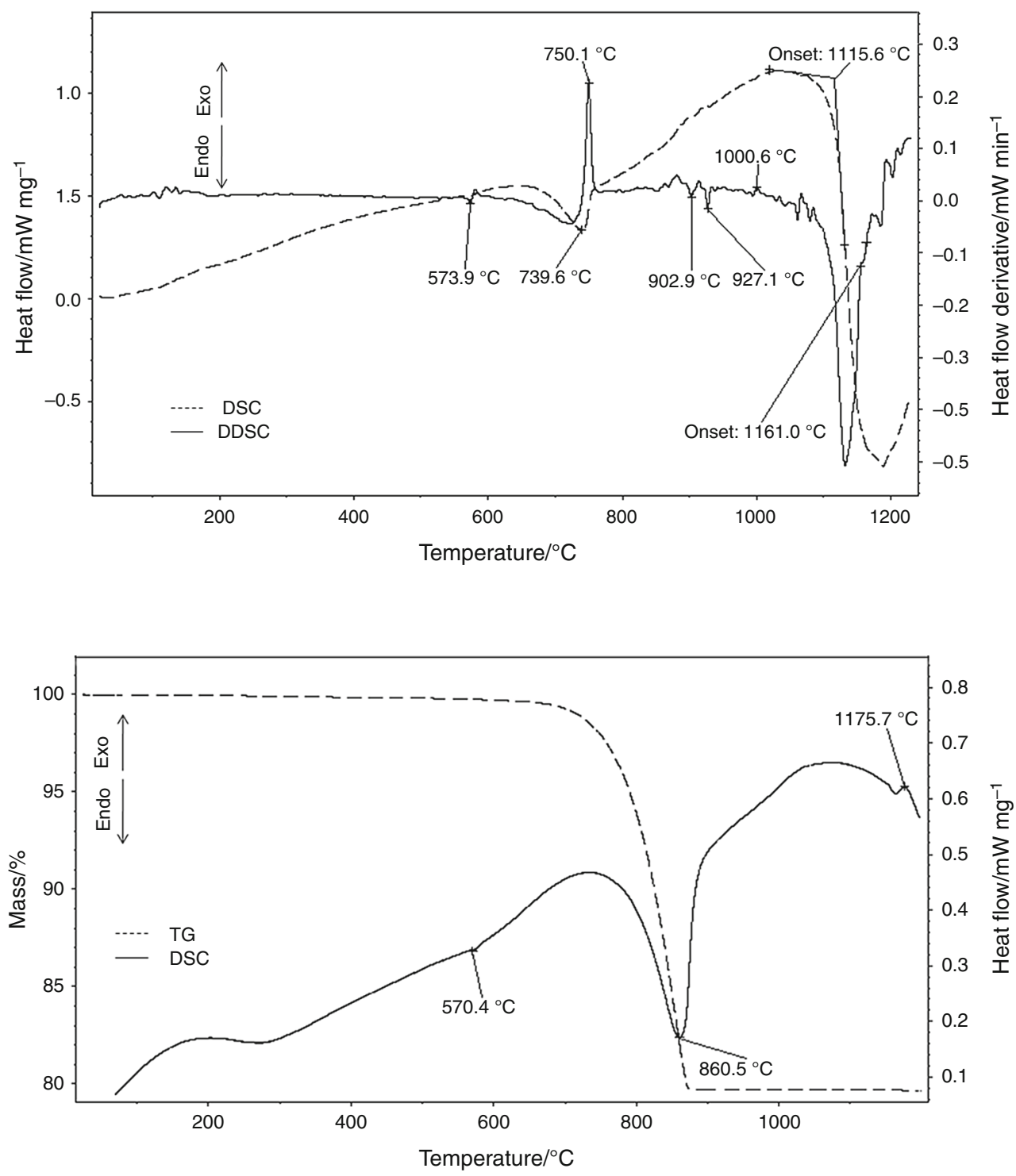

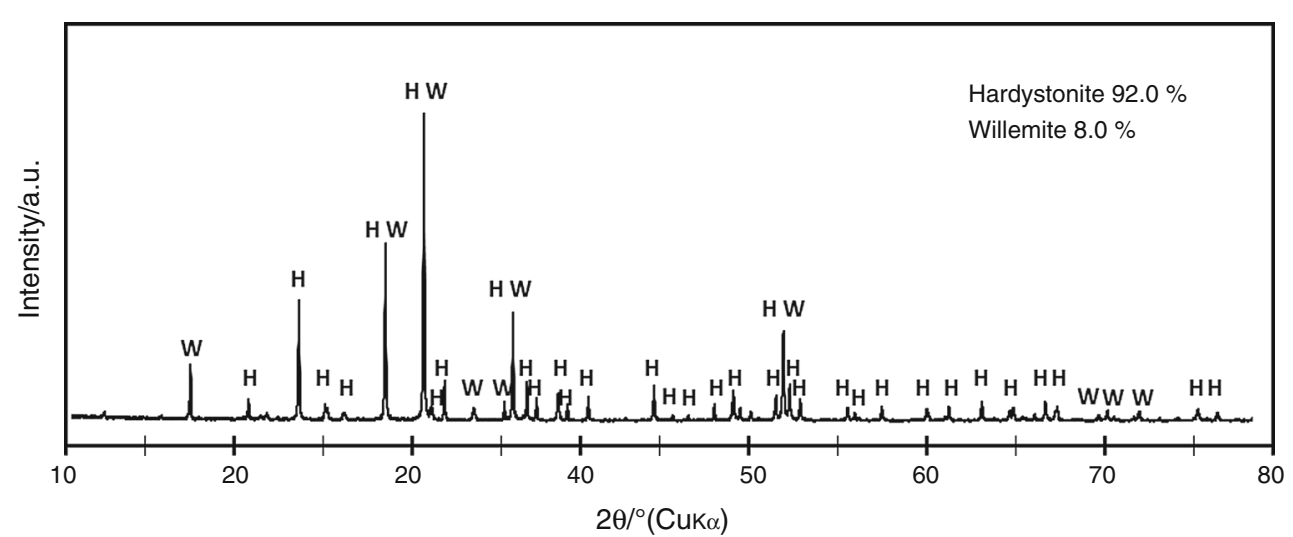

Fig. $5 \mathrm{X}$-ray diffraction pattern for stoichiometric mixture of $\mathrm{CaCO}_{3}, \mathrm{SiO}_{2}$ and $\mathrm{ZnO}$ heated for $1 \mathrm{~h}$ at $1175{ }^{\circ} \mathrm{C}$. Explanation of symbols: $\mathrm{H}-$ hardystonite, $\mathrm{W}$-willemite 
Fig. 6 Sintering curves of willemite glass-crystalline glaze and synthesized hardystonite measured by hot-stage microscope

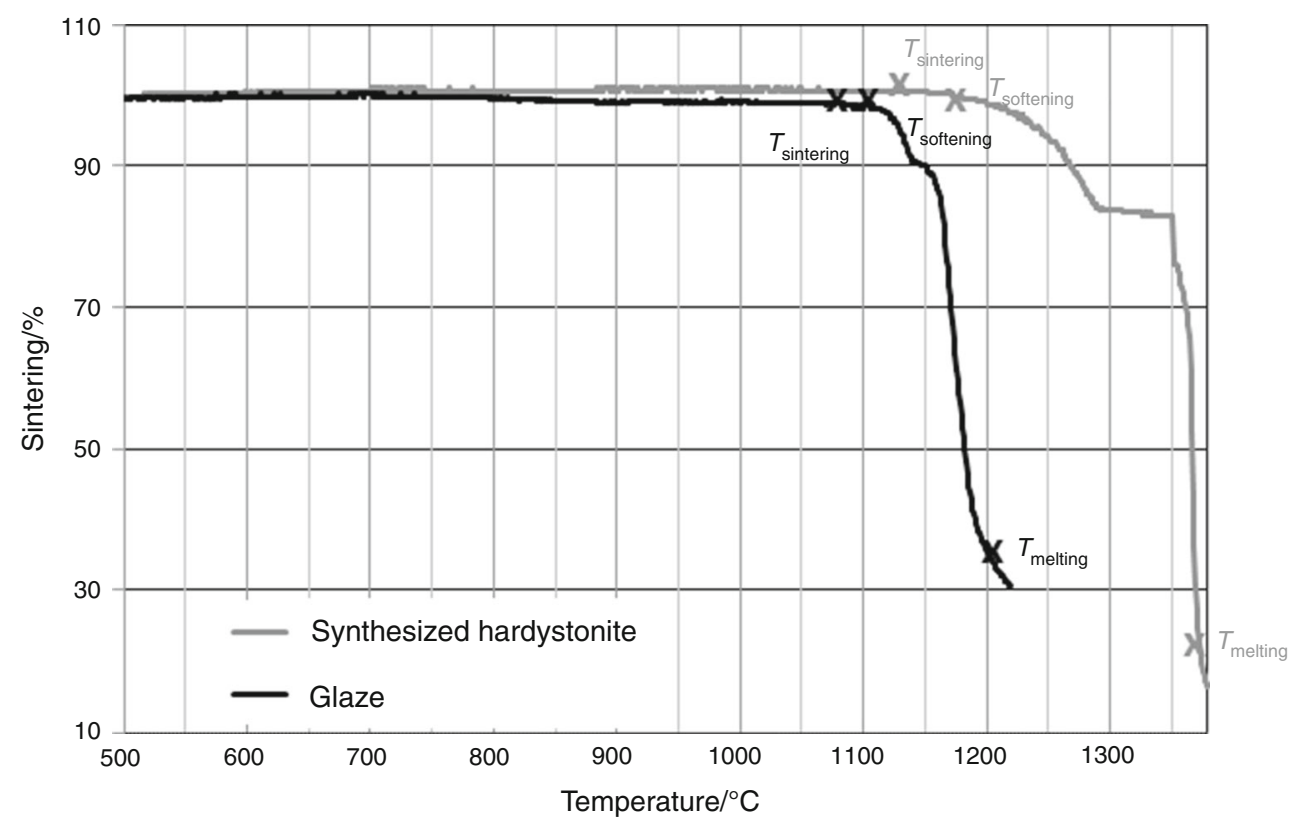

were obtained [16]. The sintering of the glaze starts at $1100{ }^{\circ} \mathrm{C}$. The softening point of the glazes is given by the rounding of the sample edges indicating the onset of melt formation in the samples. Based on sintering curve of glaze, we can observe that liquid phase is present in system above $1110{ }^{\circ} \mathrm{C}$. Complete melting of the glaze was above $1220{ }^{\circ} \mathrm{C}$. When this figure is examined, it is detected that the sintering, softening and melting temperatures were a reduction in glaze compared to the hardystonite. It is understandable due to the fact that hardystonite consists of high-melting oxides such as $\mathrm{CaO}, \mathrm{ZnO}$ and $\mathrm{SiO}_{2}$ [17].

\section{Discussion}

Two crystalline phase hardystonite and willemite were detected in glaze heated at $750{ }^{\circ} \mathrm{C}$ for $1 \mathrm{~h}$ using by XRD and SEM analysis as a results of solid-phase synthesis reaction of raw materials. Hardystonite at low temperature $\left(750{ }^{\circ} \mathrm{C}\right)$ in glaze formed easily and in a higher content than willemite due to the high reactivity of $\mathrm{CaO}$ derived from the decomposition of calcium carbonate (Fig. 3). It was confirmed by the results XRD analysis, which no registered presence of calcium oxide at these temperatures. Takesue [18] reported that willemite phase begins to form by solid diffusion of $\mathrm{ZnO}$ on the surface of $\mathrm{SiO}_{2}$ as we can observe on the SEM micrograph (Fig. 2a). Similarly as a willemite, the crystals of hardystonite also were formed on the quartz grains. It was determined using hot-stage microscopy that in glaze the liquid phase present about temperature $1110{ }^{\circ} \mathrm{C}$. This value indicates that the synthesis reactions of willemite and hardystonite occurred without the liquid phase. Synthesis reactions of both phases were progressed slowly, which explains the presence of only a small thermal effects on the DDSC curve of glaze (Fig. 3). The research proven insufficient to explain the reasons of the decomposition of hardystonite and willemite in glaze. This information agrees with the DDSC results where an endothermic reactions were identified at 902 and $927{ }^{\circ} \mathrm{C}$ (Fig. 3). It is important to decompose of hardystonite and willemite using XRD analysis not registered any new crystalline phase, only a slight increase the content of $\mathrm{ZnO}$ and $\mathrm{SiO}_{2}$ (Table 2). This issue is still in research. Hardystonite and willemite form again and coexist in glaze fired at $1150{ }^{\circ} \mathrm{C}$, when in system was identified a liquid phase. According to the results of DSC measurement, melting of potassium feldspar begins at about $1115{ }^{\circ} \mathrm{C}$ which can observe on the DSC curve as a sharp endothermic peak (Fig. 3). This effect is related to decomposition of feldspar by melting with formation of leucite $\left(\mathrm{KAlSi}_{2} \mathrm{O}_{6}\right)$ and liquid [19]. The presence of leucite was detected in glaze above $1000{ }^{\circ} \mathrm{C}$ using XRD analysis (Fig. 1; Table 2). Moreover, Fig. 2 indicates a homogeneous matrix with two type of ovoid crystals identified as hardystonite and willemite covered with liquid phase (Fig. 3). The chemical composition of this phase determined by EDS analysis is consistent with chemical composition of stoichiometric leucite crystal. However, below $1200{ }^{\circ} \mathrm{C}$ the hardystonite is melted and dissolved in the silicate melt resulting of the components of glaze. Hardystonite was not detected in the samples fired at 1200 and $1240{ }^{\circ} \mathrm{C}$; this may be explained also by the higher level of willemite which would be the major phase containing $\mathrm{Zn}$. At these temperatures, willemite is still present as a predominant crystalline phase. 


\section{Conclusions}

This work concerns the synthesis, characterization and thermal behavior of hardystonite in willemite glass-crystalline glaze. In studied glaze identified two new crystalline phases: hardystonite and willemite. Hardystonite formed at $750{ }^{\circ} \mathrm{C}$ as results of solid-phase synthesis and at $1150{ }^{\circ} \mathrm{C}$ as a crystallization in melt. Hardystonite is unstable crystalline phase in tested system. Higher than $850{ }^{\circ} \mathrm{C}$, this phase decomposed and re-formed at about $1150{ }^{\circ} \mathrm{C}$ in the presence of a liquid phase resulting from the melting of potassium feldspar and other glaze components. The melting temperature of synthesized hardystonite determined by HSM is about $1360{ }^{\circ} \mathrm{C}$. In glaze observed by using DSC method, melting and dissolution of hardystonite occurred at a lower temperature due to the presence of silicate melt.

Acknowledgements This research has been carried out thanks to financing under the framework of NCBiR (Polish National Research and Development Committee) Programme No. N N508 477734 and PBS1/B5/17/2012.

Open Access This article is distributed under the terms of the Creative Commons Attribution 4.0 International License (http://crea tivecommons.org/licenses/by/4.0/), which permits unrestricted use, distribution, and reproduction in any medium, provided you give appropriate credit to the original author(s) and the source, provide a link to the Creative Commons license, and indicate if changes were made.

\section{References}

1. Draney C. A study of macrocrystalline glazes. Manhattan: Kansas State University; 1969.

2. Shimbo F. Crystalline glazes understanding the process and materials. Kindle Edition. 2013.
3. Pacurariu C, Lazau R, Lazau I, Stoleriu S. Kinetic study of the crystallization processes of some decorative ceramic glazes. J Therm Anal Calorim. 2007;88:641-5.

4. Creber D. Crystaline glazes. London: A\&C Black; 2005.

5. Karasu B, Turan S. Effects of cobalt, manganese and titanium oxide additions on the microstructures of zinc containing soft porcelain glazes. J Eur Ceram Soc. 2002;22:1447-55.

6. Dakhai S, Orlova L, Mikhailenko N. Types and composition of crystalline glazes. Glass Ceram. 1999;56:177-80.

7. Sułowska J, Wacławska I, Szumera M. Comparative study of zinc addition effect on thermal properties of silicate and phosphate glasses. J Therm Anal Calorim. 2016;123:1091-8.

8. Fröberg L. Factors affecting raw glaze properties. Åbo: Åbo Akademi; 2007.

9. Wu C, Chang J, Zhai W. A novel hardystonite bioceramic: preparation and characteristics. Ceram Int. 2005;31:27-31.

10. Jianga L, Xiaoa S, Yanga X, Zhanga B, Liua X. Preparation and luminescence properties of yellow long-lasting phosphor $\mathrm{Ca}_{2}$ $\mathrm{ZnSi}_{2} \mathrm{O}_{7}: \mathrm{Eu}^{2+}$, Dy ${ }^{3+}$. Mater Sci Eng B. 2013;178:123-6.

11. Jamaludin $\mathrm{A}$, Kasim $\mathrm{S}$, Ahmad $\mathrm{Z}$. The effect of $\mathrm{CaCO}_{3}$ addition on the crystallization behavior of $\mathrm{ZnO}$ crystal glaze fired a different gloss firing and crystallization temperatures. Sci Sinter. 2010;42:345-55.

12. Omar A, Abdel-Hameed S. Crystallization of calcium zinc aluminosilicate glasses. Ceram Silik. 2009;53:171-9.

13. Rietveld R. Line profiles of neutron powder-diffraction peaks for structure refinement. Acta Cryst. 1967;22:151-2.

14. Małecki A. Wpływ różnych czynników na wyniki pomiarów DTA/DSC/TG. Conference materials-III Szkoła Analizy Termicznej. Zakopane. 2002:77-159.

15. Lide D. CRC handbook of chemistry and physics. Boca Raton: Florida; 2009.

16. Paganelli M, Sighinolfi D. Understanding the behavior of glazes: new possibilities using the automatic hot stage microscope Misura. Ceram Ind. 1997;17:69-73.

17. Segnit R. Phase equilibria in the $\mathrm{ZnO}-\mathrm{CaO}-\mathrm{SiO}_{2}$ system. J Am Ceram Soc. 1954;37:273-7.

18. Takesue M, Hayashi H, Smith $\mathrm{H}$. Thermal and chemical methods for producing zinc silicate (willemite): a review. Prog Cryst Growth Charact Mater. 2009;55:98-124.

19. Handke M. Krystalochemia krzemianów. Kraków: Uczelniane Wydawnictwa Naukowe AGH; 2008. 